\title{
Ozone concentrations, flux and potential effect on yield during wheat growth in the Northwest-Shandong Plain of China
}

\author{
Zhilin $\mathrm{Zhu}^{1, *}$, Xiaomin Sun ${ }^{1, *}$, Fenghua Zhao ${ }^{1}$, Franz X. Meixner ${ }^{2}$ \\ 1. Key Laboratory of Ecosystem Network Observation and Modeling, Institute of Geographic Sciences and Natural Resources Research, \\ Chinese Academy of Sciences, Beijing 100101, China. E-mail: zhuzl@igsnrr.ac.cn \\ 2. Biogeochemistry Department, Max-Planck-Institute for Chemistry, 55128 Mainz, Germany
}

\section{A R T I C L E I N F O}

Article history:

Received 10 October 2014

Revised 8 December 2014

Accepted 15 December 2014

Available online 5 May 2015

Keywords:

Ozone concentration

Ozone flux

Deposition velocity

Eddy covariance

Yield loss estimation

Cropland ecosystem

\begin{abstract}
A B S T R A C T
Ozone $\left(\mathrm{O}_{3}\right)$ concentration and flux $\left(\mathrm{F}_{\mathrm{o}}\right)$ were measured using the eddy covariance technique over a wheat field in the Northwest-Shandong Plain of China. The $\mathrm{O}_{3}$-induced wheat yield loss was estimated by utilizing $\mathrm{O}_{3}$ exposure-response models. The results showed that: (1) During the growing season (7 March to 7 June, 2012), the minimum (16.1 ppbV) and maximum (53.3 ppbV) mean $\mathrm{O}_{3}$ concentrations occurred at approximately 6:30 and 16:00, respectively. The mean and maximum of all measured $\mathrm{O}_{3}$ concentrations were 31.3 and $128.4 \mathrm{ppbV}$, respectively. The variation of $\mathrm{O}_{3}$ concentration was mainly affected by solar radiation and temperature. (2) The mean diurnal variation of deposition velocity $\left(V_{d}\right)$ can be divided into four phases, and the maximum occurred at noon (12:00). Averaged $V_{d}$ during daytime (6:00-18:00) and nighttime (18:00-6:00) were 0.42 and $0.14 \mathrm{~cm} / \mathrm{sec}$, respectively. The maximum of measured $V_{d}$ was about $1.5 \mathrm{~cm} / \mathrm{sec}$. The magnitude of $V_{d}$ was influenced by the wheat growing stage, and its variation was significantly correlated with both global radiation and friction velocity. (3) The maximum mean $F_{\mathrm{o}}$ appeared at 14:00, and the maximum measured $F_{\mathrm{o}}$ was $-33.5 \mathrm{nmol} /\left(\mathrm{m}^{2} \cdot \mathrm{sec}\right)$. Averaged $F_{0}$ during daytime and nighttime were -6.9 and $-1.5 \mathrm{nmol} /\left(\mathrm{m}^{2} \cdot \mathrm{sec}\right)$, respectively. (4) Using $\mathrm{O}_{3}$ exposure-response functions obtained from the USA, Europe, and China, the $\mathrm{O}_{3}$-induced wheat yield reduction in the district was estimated as $12.9 \%$ on average (5.5\%-23.3\%). Large uncertainties were related to the statistical methods and environmental conditions involved in deriving the exposure-response functions.

(c) 2015 The Research Center for Eco-Environmental Sciences, Chinese Academy of Sciences.
\end{abstract}

Published by Elsevier B.V.

\section{Introduction}

Ground-level ozone $\left(\mathrm{O}_{3}\right)$ is a secondary pollutant with adverse effects on plant growth, photosynthesis, and crop yields (Heck et al., 1982; Cape, 2008; Feng et al., 2008). The $\mathrm{O}_{3}$ concentration is determined by its photochemical reactions with $\mathrm{NO}_{x}\left(\mathrm{NO}+\mathrm{NO}_{2}\right)$ and VOCs (Volatile Organic Compounds) as well as horizontal and vertical large-scale transport (Crutzen et al., 1999; Cape, 2008). According to long-term observations across the globe, ground $\mathrm{O}_{3}$ concentration levels have been increasing in the past several decades (Monks, 2000; Vingarzan, 2004). In China, fast-paced industrialization and ever-increasing numbers of fossil-fueled vehicles have produced significant amounts of VOCs and $\mathrm{NO}_{x}$, which have led to rapidly increasing atmospheric $\mathrm{O}_{3}$ concentrations (Wang et al., 2009; Li et al., 2014). The elevated $\mathrm{O}_{3}$ concentration is threatening crop production in China (Aunan et al., 2000; Wang and Mauzerall, 2004; Wang et al., 2007; Zhu et al., 2011).

Two kinds of metrics, $\mathrm{O}_{3}$ concentration or exposure-based indices, and flux-based indices, were applied to assess the effect

\footnotetext{
* Corresponding authors. E-mail: sunxm@igsnrr.ac.cn (Xiaomin Sun).
} 
of $\mathrm{O}_{3}$ on plants and ecosystems (Musselman et al., 2006; Pleijel et al., 2007). The former are metrics related to the atmospheric environment that do not consider the status of vegetation and ecosystems, e.g., stomatal conductance, leaf area index, and growing stages. Plant response to $\mathrm{O}_{3}$ is closely related to the amount absorbed into leaf tissue, so stomatal $\mathrm{O}_{3}$ uptake is considered a better metric than ambient $\mathrm{O}_{3}$ concentration to evaluate the $\mathrm{O}_{3}$-induced yield loss (Pleijel et al., 2004; Paoletti and Manning, 2007). One of the well-established methods to quantify stomatal $\mathrm{O}_{3}$ uptake is to measure total $\mathrm{O}_{3}$ flux $\left(\mathrm{F}_{\mathrm{o}}\right)$ over an ecosystem and then partition $F_{\mathrm{o}}$ into stomatal $\left(F_{\mathrm{st}}\right)$ and non-stomatal uptake $\left(F_{n s}\right)$ by using resistance models (Gerosa et al., 2003; Lamaud et al., 2009).

Currently, the eddy covariance method is considered the best micrometeorological technique for measuring ecosystem fluxes (Grünhage et al., 2000; Baldocchi, 2003). Due to a lack of robust and high performance fast-response gas analyzers that can be deployed in the field on a long-term basis, several short-term $\mathrm{O}_{3}$ flux measurements have been carried out in the past few decades (Gerosa et al., 2003; Lamaud et al., 2009). In China, studies of the effects of $\mathrm{O}_{3}$ on plants have mainly centered on OTC (open top chamber) or FACE (free-air concentration enhancement) experiments (Feng et al., 2003; Zhu et al., 2011; Feng et al., 2012). To our knowledge, there have been few investigations on $\mathrm{O}_{3}$ flux at the ecosystem level in China.

One purpose of studying $\mathrm{O}_{3}$ concentration and flux over a cropland ecosystem is to assess the yield loss caused by $\mathrm{O}_{3}$. To quantify these losses, some $\mathrm{O}_{3}$ exposure/flux-response models have been generated by using OTC or FACE experiments (Heck et al., 1982; Mills et al., 2007; Feng et al., 2012; Wang et al., 2012). Although flux-based indices have advantages over exposure-based indices owing to their linkage to stomatal uptake of plants, there are some practical limitations that hinder their use in current research. Such limitations include the lack of continuous stomatal $\mathrm{O}_{3}$ flux estimations and suitable flux-based assessment models. In contrast, yield loss estimations utilizing $\mathrm{O}_{3}$ exposure-response functions are relatively easy (Wang and Mauzerall, 2004; Van Dingenen et al., 2009; Avnery et al., 2011).

The Northwest-Shandong Plain of China is an important grain production base, and wheat is a high $\mathrm{O}_{3}$-sensitivity crop (Mills et al., 2007). To investigate the current $\mathrm{O}_{3}$ status over the cropland ecosystem and to assess the effect of $\mathrm{O}_{3}$ on crop yield, $\mathrm{O}_{3}$ concentration and flux over a wheat field were measured by using the eddy covariance technique. The objectives of the study were to investigate: (1) the relationship of $\mathrm{O}_{3}$ concentration with environmental factors and the diurnal and seasonal variations of $\mathrm{O}_{3}$ concentration; (2) the relationships of $\mathrm{O}_{3}$ deposition velocity and flux with environmental factors or other fluxes as well as their diurnal and phenological variations; and (3) the $\mathrm{O}_{3}$-induced wheat yield loss at current $\mathrm{O}_{3}$ levels by using exposure-response functions.

\section{Materials and methods}

\subsection{Site description}

The observations were conducted over a winter wheat (Triticum aestivum L.) field at the Yucheng Comprehensive Experiment
Station of the Chinese Academy of Sciences $\left(36^{\circ} 50^{\prime} \mathrm{N}, 116^{\circ} 34^{\prime} \mathrm{E}\right.$, $28 \mathrm{~m}$ asl.; Shandong Province, China). The site is located in the Yellow River alluvial plain of the North China Plain, characterized by loamy soil texture as well as a semiarid and warm temperate climate. The mean annual temperature and precipitation are $13.4^{\circ} \mathrm{C}$ and $567 \mathrm{~mm}$, respectively. The main growing season of winter wheat is from March to early June. The experimental site is fairly flat, and fetch requirements for eddy covariance measurements are well satisfied within $200 \mathrm{~m}$ of the instrument locations. The canopy height of the winter wheat increased from $0.05 \mathrm{~m}$ to $0.75 \mathrm{~m}$ during the field experiment from 7 March to 7 June, 2012.

\subsection{Data collection}

The absolute concentration of ambient $\mathrm{O}_{3}$ was measured with a slow-response portable UV-absorption based $\mathrm{O}_{3}$ analyzer (Model 205, 2B Technologies Inc. CO., Boulder, Colorado, USA; hereafter referred to as M205). It has a detection limit of $1 \mathrm{ppbV}$ and its output rate was set to $2 \mathrm{sec}$. Ozone flux was measured with the eddy covariance method in combination with observations from the Chinese Terrestrial Ecosystem Flux Observational Research Network (ChinaFLUX) (Yu et al., 2006). The instrumentation includes a 3D sonic anemometer (CSAT3, Campbell Scientific Instruments, Logan, Utah, USA) and an open-path $\mathrm{CO}_{2} / \mathrm{H}_{2} \mathrm{O}$ gas analyzer (LI-7500, LI-COR Biosciences, Lincoln, Nebraska, USA). The $\mathrm{O}_{3}$ fluctuation was measured with a fast-response $\mathrm{O}_{3}$ analyzer (Enviscope $\mathrm{GmbH}$, Frankfurt am Main, Germany), hereafter referred to as ENVI. The measurement principle is based on the chemiluminescence reaction of $\mathrm{O}_{3}$ with an ozone-sensitive dye layer on an aluminum plate placed in the cell. Although its response time can reach $0.1 \mathrm{sec}$, the sensitivity is affected by the consumption of dye and environmental conditions, particularly the air humidity (Güsten et al., 1996; Muller et al., 2010). More information about the analyzer can be found in Zahn et al. (2012). Air was drawn into the two analyzers through two PTFE (Teflon) tubes that were $3 \mathrm{~m}$ long with a $4 \mathrm{~mm}$ interior diameter. The mean delay time $(2.8 \mathrm{sec})$ was calculated by the maximum covariance method. The ENVI's output signal (in $\mathrm{mV}$ ) was calibrated by the ambient $\mathrm{O}_{3}$ concentration. Micrometeorological and radiation variables were also measured, including air temperature and relative humidity (HMP45C, Vaisala Co., Finland), wind speed (A100R, Vector Instruments, UK), net radiation (CNR1, Kipp \& Zonen, the Netherlands), and photosynthetically active radiation (LI-190SB, LI-COR Biosciences, USA).

All sensors were installed at $2.2 \mathrm{~m}$ height. The sampling frequency was $10 \mathrm{~Hz}$. Two gas intake tubes were mounted next to the sonic anemometer center with $0.2 \mathrm{~m}$ horizontal separation. Due to the continuous consumption of organic dye, ENVI's sensitivity slowly decreased with time. To maintain high sensitivity, we replaced the organic dye disc every 3 to 4 days. $10 \mathrm{~Hz}$ raw data from the eddy covariance (EC) system and 30-min mean data were recorded by a data-logger (CR5000, Campbell Scientific Instrument, Logan, Utah, USA).

\subsection{Eddy covariance $\mathrm{O}_{3}$ flux calculation and data post-processing}

The eddy covariance method is based on the statistics involved in vertical turbulent exchange of scalars. Because the ENVI's 
signal output is a relative measure of $\mathrm{O}_{3}$ and its stability is affected by the consumption of $\mathrm{O}_{3}$-sensitive dye and environmental conditions, it needs to be simultaneously calibrated using the absolute $\mathrm{O}_{3}$ concentration. In this study, the "Ratio Method" was used to calibrate the ENVI's signal output (X), which means that $X$ (in $\mathrm{mV}$ ) is proportional to the absolute ambient $\mathrm{O}_{3}$ concentration over a $30 \mathrm{~min}$ period. Based on this assumption, the ozone deposition velocity $\left(V_{d}, \mathrm{~cm} / \mathrm{sec}\right)$, defined as the $\mathrm{O}_{3}$ flux divided by $\mathrm{O}_{3}$ concentration, can be calculated by (Muller et al., 2010):

$V_{\mathrm{d}}=-\frac{\overline{w^{\prime} X^{\prime}}}{\bar{X}}$

where, $w$ is vertical wind speed. The overbar denotes time average and the prime signs indicate the fluctuation of each variable. The role of the minus sign in Eq. (1) is to maintain a positive $V_{d}$, because $\mathrm{O}_{3}$ flux is always directed downward (negative). $\mathrm{V}_{\mathrm{d}}$ can be understood as the normalized $\mathrm{O}_{3}$ flux, and is often used to compare deposition characteristics at different surfaces (Wesely and Hicks, 2000; Fowler et al., 2009). The raw $\mathrm{O}_{3}$ flux $\mathrm{F}_{\mathrm{o} \_ \text {raw }}\left(\mathrm{nmol} /\left(\mathrm{m}^{2} \cdot \mathrm{sec}\right)\right)$ can be given as:

$F_{\text {o_raw }}=-\bar{\rho}_{\mathrm{o}} V_{\mathrm{d}}=\bar{\rho}_{\mathrm{o}} \frac{\overline{w^{\prime} X^{\prime}}}{\bar{X}}$

where, $\bar{\rho}_{0}$ is the mean $\mathrm{O}_{3}$ density $\left(\mathrm{nmol} / \mathrm{m}^{3}\right)$ derived by combining M205 output (ppbV) and atmospheric temperature and pressure.

In practice, $\mathrm{O}_{3}$ flux was processed by EddyPro® software (LI-COR, Lincoln, NE, USA) with a series of corrections. Double rotation was utilized to correct the tilt errors (Wilczak et al., 2001). Webb, Pearman, and Leuning (WPL) corrections for a closed-path system were performed to account for $\mathrm{O}_{3}$ flux (Webb et al., 1980).

\subsection{Calculation of $\mathrm{O}_{3}$ concentration-based indices}

In this study, two concentration-based indices were used to assess wheat yield loss during the growing season (3 months). The M7 index (ppbV) is the 7-hr (9:00-16:00) mean $\mathrm{O}_{3}$ concentration and the AOT40 index (ppmV.hr) is the accumulated hourly ozone concentration above a $40 \mathrm{ppbV}$ threshold. They are calculated according to Van Dingenen et al. (2009):

$\mathrm{M} 7=\frac{1}{N} \sum_{1}^{N} \bar{C}_{03[9-16]}$

$\mathrm{AOT} 40=\sum\left(C_{03}-40\right) \quad C_{03}>40 \mathrm{ppbV}$

where, $\mathrm{C}_{\mathrm{O} 3}$ (ppbV) is hourly-mean $\mathrm{O}_{3}$ concentration. Gaps in $\mathrm{O}_{3}$ concentrations caused by instrument malfunction and power shortage were filled using two methods. If missed data spanned less than 4 sequential gaps, the linear interpolation method was used, otherwise, the mean diurnal variation method was applied (Falge et al., 2001).

\subsection{Data statistical methods}

Statistical analysis was performed with MATLAB® 2011 (Mathworks) and Microsoft Office Excel 2003 for Windows. We used the standard deviation (std) to indicate the temporal variance of an individual variable. Outliers were removed prior to subsequent analysis. The main screening criteria are: 0 to $200 \mathrm{ppbV}$ for $\mathrm{O}_{3}$ concentration and -35 to $0 \mathrm{nmol} /\left(\mathrm{m}^{2} \cdot \mathrm{sec}\right)$ for $\mathrm{O}_{3}$ flux. Data that corresponded to periods of instrument malfunction, instrument calibration, and replacement of the disc were removed.

\section{Results and discussion}

\subsection{Response of $\mathrm{O}_{3}$ concentrations to environmental factors}

\subsubsection{Mean diurnal variations of $\mathrm{O}_{3}$ concentration}

Fig. 1a displays the mean diurnal variation of 30-min averaged $\mathrm{O}_{3}$ concentration for the entire growing season. To compare its variation with other environmental factors, we also present mean diurnal variations of global radiation $(Q)$ and air temperature $(\mathrm{T})$ (Fig. 1b). The lowest value (16.1 ppbV) of mean $\mathrm{O}_{3}$ concentration occurred around 6:30, approximately a half hour later than mean sunrise time. It then continuously increased in the morning and early afternoon. The highest value (53.3 ppbV) appeared at 16:00, $4 \mathrm{hr}$ later than the global radiation peak $(\sim 12: 00)$ and slightly later than the air temperature peak (Fig. 1b). $\mathrm{O}_{3}$ then rapidly fell until roughly 20:00. During the night, $\mathrm{O}_{3}$ always had a downtrend until the next morning. Daytime (6:00-18:00) and nighttime (18:00-6:00, hereafter) mean $\mathrm{O}_{3}$ concentrations were $39.5 \pm 22.1$ and $20.7 \pm 14.1 \mathrm{ppbV}$ (mean $\pm \mathrm{std}$, hereafter), respectively. The mean $\mathrm{O}_{3}$ concentration during the growing seasons was $31.3 \pm 22.3 \mathrm{ppbV}$.

The diurnal variation of $\mathrm{O}_{3}$ concentration depends on the balance of many factors affecting $\mathrm{O}_{3}$ formation (e.g., local photochemical reactions and horizontal or vertical transport) and destruction (e.g., deposition or chemical reactions) (Crutzen et al., 1999; Cape, 2008; Lin et al., 2008). In the early afternoon, in spite of the gradual decrease of radiation, the increasing temperature resulted in higher levels of chemical precursors, which then led to the rise in $\mathrm{O}_{3}$ concentration. In the evening, the slow decrease of $\mathrm{O}_{3}$ concentration may result from the balance between transported $\mathrm{O}_{3}$ from the upper atmosphere and weak decomposition. The extreme value occurred when the production and destruction velocities of $\mathrm{O}_{3}$ were equal. Diurnal variation patterns (particularly the peak times) are not the same in different areas. Our results agree well with the typical diurnal patterns for $\mathrm{O}_{3}$ concentration at low-elevation locations (Kelly et al., 1984; Lin et al., 2008). However, it differed from the patterns from high-elevation sites. For example, the maximum value at the Waliguan site in the Qinghai-Tibet Plateau (3810 $\mathrm{m}$ asl) took place at night or early morning, and there was little diurnal variation. This is caused by the extremely low levels of $\mathrm{O}_{3}$ precursors in the closed natural background condition (Ma et al., 2002; Wang et al., 2006). The difference in $\mathrm{O}_{3}$ concentration during the day and night showed that $\mathrm{O}_{3}$ was produced by local photochemical reactions at this site (Crutzen et al., 1999; Xu et al., 2008).

\subsubsection{Seasonal variation of $\mathrm{O}_{3}$ concentration}

Fig. 2 shows the daily and 7-hr averaged $\mathrm{O}_{3}$ concentrations (M24 and M7) during the entire growing season. The overall seasonal change showed an increasing trend, in spite of the lower value that occurred at end of March. The ensemble-averaged $\mathrm{O}_{3}$ 

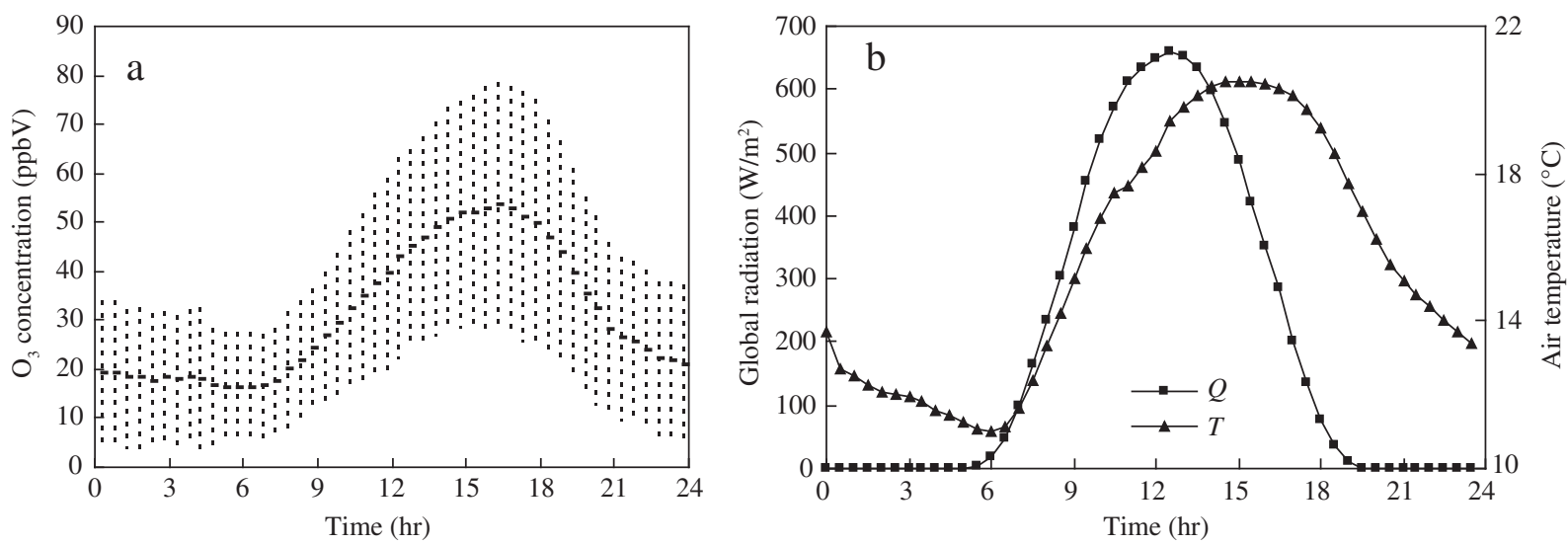

Fig. 1 - Mean diurnal variations of (a) 30-min averaged $\mathrm{O}_{3}$ concentrations as well as (b) global radiation (Q) and air temperature (T). Top and bottom of vertical lines represent mean \pm std.

concentrations in March, April, May, and from 1 to 7 of June were $21.6 \pm 12.5,25.6 \pm 15.7,42.1 \pm 24.3$, and $43.8 \pm 27.5 \mathrm{ppbV}$, respectively. The maximum of the 30 -min mean $\mathrm{O}_{3}$ concentrations was 128.4 ppbV at 16:30, 27 May 2012. The variation of M7 was similar to M24, and the final M7 during the growing season was $45.1 \mathrm{ppbV}$. The seasonal changes of $\mathrm{O}_{3}$ concentration may be related to emissions of VOC and $\mathrm{NO}_{x}$, which are also affected by radiation and temperature (Dueñas et al., 2002; Cape, 2008).

2.1.3. Relations of $\mathrm{O}_{3}$ concentration and environmental variables For a given location, the $\mathrm{O}_{3}$ concentration variation was dependent on meteorological variables, such as global radiation, temperature, and wind speed (Dueñas et al., 2002; Cape, 2008; David and Nair, 2011). Because the variations of $\mathrm{O}_{3}$ concentration and radiation were out-of-phase (Fig. 1), the correlation between $\mathrm{O}_{3}$ concentration and the 3-hr-ahead global radiation were the most significant, see Fig. 3a. The out-of-phase phenomenon may be explained by the time required for the following processes. First solar radiation heats the surface, which results in more emissions of $\mathrm{NO}_{x}$ and VOCs from the surface. These emissions are then transported above the crop canopy by turbulent motions. Fig. 3b presents

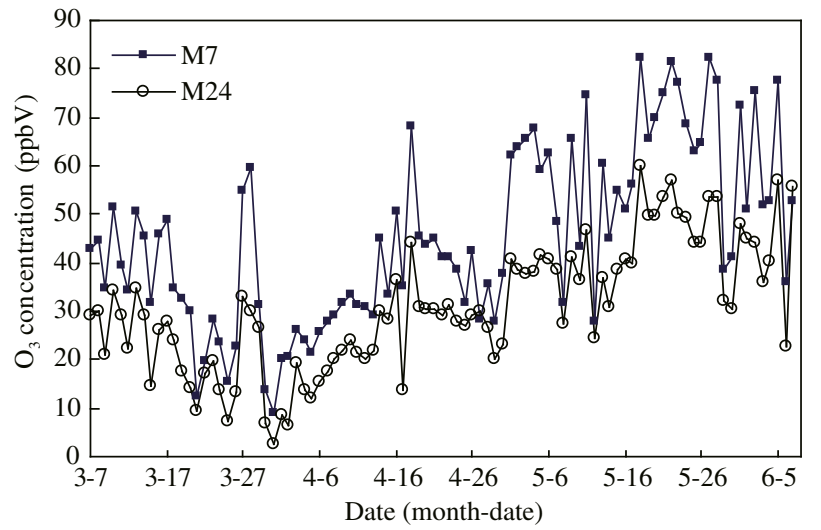

Fig. 2 - Seasonal changes of 7-hr (9:00-16:00) and daily-averaged $\mathrm{O}_{3}$ concentrations (M7 and M24) during the growing seasons (7 March to 7 June, 2012). the relationship between $\mathrm{O}_{3}$ concentration and air temperature, which was fitted by a quadratic equation. As air temperature change is primarily driven by solar radiation, temperature can be regarded as an indirect influencing factor for $\mathrm{O}_{3}$ formation.

\subsection{Response of $\mathrm{O}_{3}$ deposition velocity and flux to environmental variables}

\subsubsection{Mean diurnal variations of deposition velocity}

Fig. 4 shows the mean diurnal variation of 30-min averaged $V_{d}$ and friction velocity $\left(u^{*}\right)$ during the growing season. The diurnal variation of mean $V_{d}$ can be roughly divided into four stages: (1) rapid increase in the early morning ( 7:00-10:00); (2) stable variation around noon ( 10:00-15:00) with a range of 0.45$0.55 \mathrm{~cm} / \mathrm{sec}$ and a maximum at approximately 12:00; (3) relatively fast decrease in the later afternoon ( 15:00-19:00); and (4) slight gradual changes during the night ( 19:00-7:00) with a range of $0.05-0.15 \mathrm{~cm} / \mathrm{sec}$. During the observation period, average $V_{d}$ during the daytime and at nighttime were 0.42 and $0.14 \mathrm{~cm} / \mathrm{sec}$, respectively.

The diurnal variation of $\mathrm{V}_{\mathrm{d}}$ is affected by many factors, e.g., radiation, turbulent intensity, and atmospheric humidity (Fowler et al., 2009; Turnipseed et al., 2009; Zona et al., 2014). In the morning, the increasing radiation results in stronger turbulence (described by friction velocity $u^{*}$ ) (Fig. 4b), which facilitates $\mathrm{O}_{3}$ transport to the underlying surface. Elevated radiation can also cause stomata to open, allowing easy access for $\mathrm{O}_{3}$. Thus, $\mathrm{V}_{\mathrm{d}}$ increased rapidly during the morning. Around noon, $u^{*}$ remained strong with stable variation, and wheat stomata were predominantly opened at this time. $V_{d}$ showed a stable variation with large deposition velocity during this period because of these factors. $V_{d}$ displays a downward trend and reaches a relatively low level in the afternoon due to the weak turbulent exchange and gradually closing stomata. At night, though the wheat stomata are almost completely closed, the slow $V_{d}$ may result from the reaction of $\mathrm{O}_{3}$ with other chemicals (e.g., NO from soil) or absorption by soil and stems (Zona et al., 2014). The diurnal variation was similar to that measured on a barley field (Gerosa et al., 2004) and on ponderosa pine (Kurpius et al., 2002). The average $V_{d}$ was comparable with the results from 

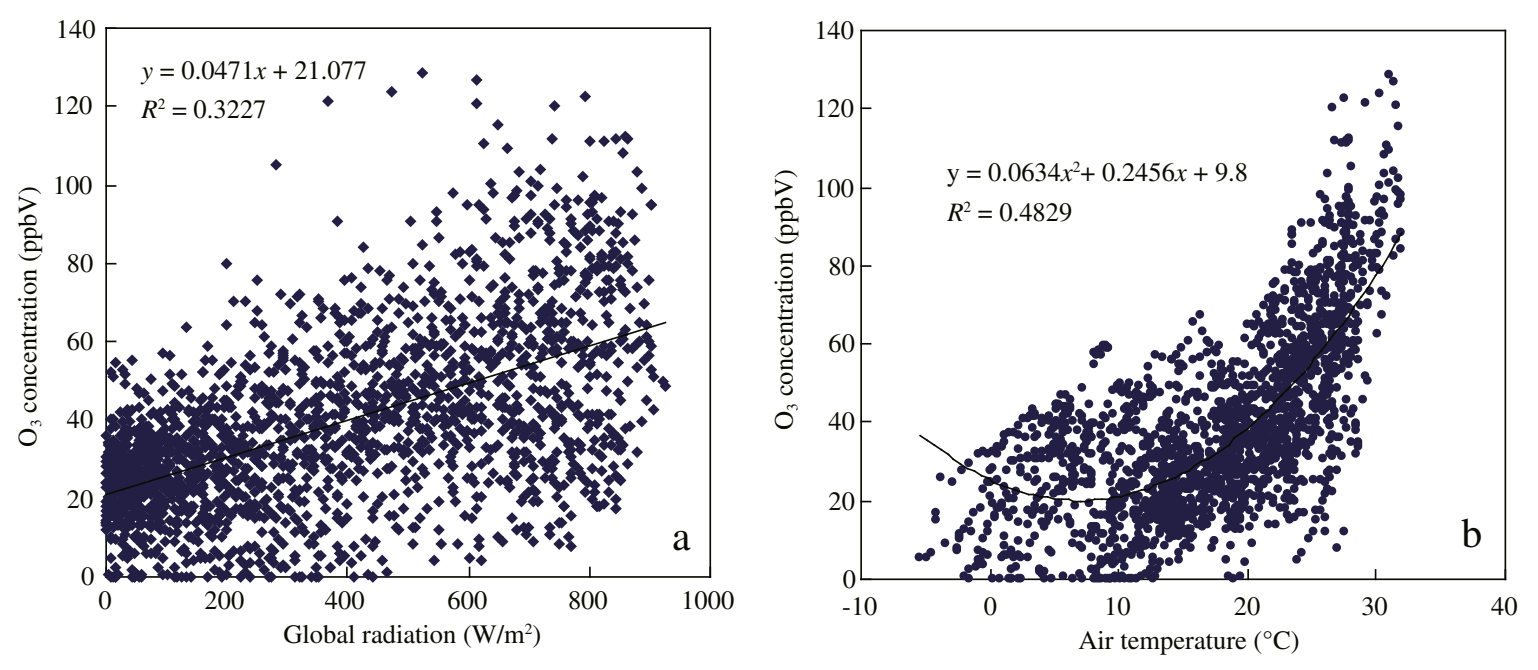

Fig. 3 - Relationships of daytime $\mathrm{O}_{3}$ concentration with (a) global radiation (Q) and (b) air temperature (T). Global radiation was shifted forward by $3 \mathrm{hr}$.

vineyard and cotton surfaces in the USA, which were 0.5 and $0.8 \mathrm{~cm} / \mathrm{sec}$, respectively (Padro, 1996).

Fig. 5a compares the mean diurnal variations of average $V_{d}$ in different periods or months. To compare these with the crop growth status, the crop heights $\left(h_{c}\right)$ and Leaf Area Index (LAI) are shown in Fig. 5b. Clearly, there were large differences in the values and diurnal variation of $\mathrm{V}_{\mathrm{d}}$ due to the differences in the surface status. At the beginning of the observation period (March), the wheat was short ( $h_{\mathrm{c}}$ ranged from 10 to $30 \mathrm{~cm}$,) and most of the surface was bare soil (LAI was between 0.3 and 1). $V_{d}$ showed a symmetrical diurnal cycle during this period with the maximum of $0.4 \mathrm{~cm} / \mathrm{sec}$ at midday. In the vegetative stages (April to May), $h_{c}$ increased from 30 to $75 \mathrm{~cm}$ and LAI varied between 1 and 2.7. During this period, the maximum $V_{d}$ appeared around noon and reached as high as $0.7 \mathrm{~cm} / \mathrm{sec}$. At the end of the growth stage (from 1 to 7 of June), most leaves were senescent and stomata were nearly closed. $V_{d}$ reached its peak in the early morning and the mean $V_{d}$ was the smallest $(\sim 0.35 \mathrm{~cm} / \mathrm{sec})$ during this period.

There is large variability in $V_{d}$ between different surfaces and different crop growing stages. Generally, abiotic surfaces with very little organic matter (e.g., desert or snow) have a deposition velocity on the order of $0.1 \mathrm{~cm} / \mathrm{sec}$ or less (Güsten et al., 1996; Wesely and Hicks, 2000). The relatively large daytime $\mathrm{V}_{\mathrm{d}}(\sim 0.4 \mathrm{~cm} / \mathrm{sec})$ in March $\left(\mathrm{V}_{\mathrm{d}} 3\right)$ might be driven by the chemical reaction of $\mathrm{O}_{3}$ with $\mathrm{NO}$ and other gases emitted from soil as well as stomata uptake of $\mathrm{O}_{3}$ (Zona et al., 2014). The phenological variation of $\mathrm{V}_{\mathrm{d}}$ was similar to that observed in some previous studies (Gerosa et al., 2003, 2004). For example, mean $V_{d}$ over barley in Italy gradually increased from seedling growth to stem elongation and reached its maximum soon after anthesis (i.e., the grain filling period) when photosynthesis was at the highest level (Gerosa et al., 2004). In our study, the $V_{d}$ in April and May was the same magnitude as the $V_{d}$ over the barley field. During this period the maximum of averaged $V_{d}$ could reach approximately $0.8 \mathrm{~cm} / \mathrm{sec}$ around noon (see $V_{d} 4$ and $V_{d} 5$ in Fig. 5a). During the latter part of the growing season of barley, $V_{d}$ decreased gradually with the maturation of the barley and leaf senescence. The midday $V_{d}$ also noticeably decreased during this period, leading to an earlier maximum and skewing the diurnal variation pattern towards morning (Gerosa et al., 2004). A similar diurnal variation pattern was found in our study (see $V_{d} 6$ in Fig. $5 a$ ).
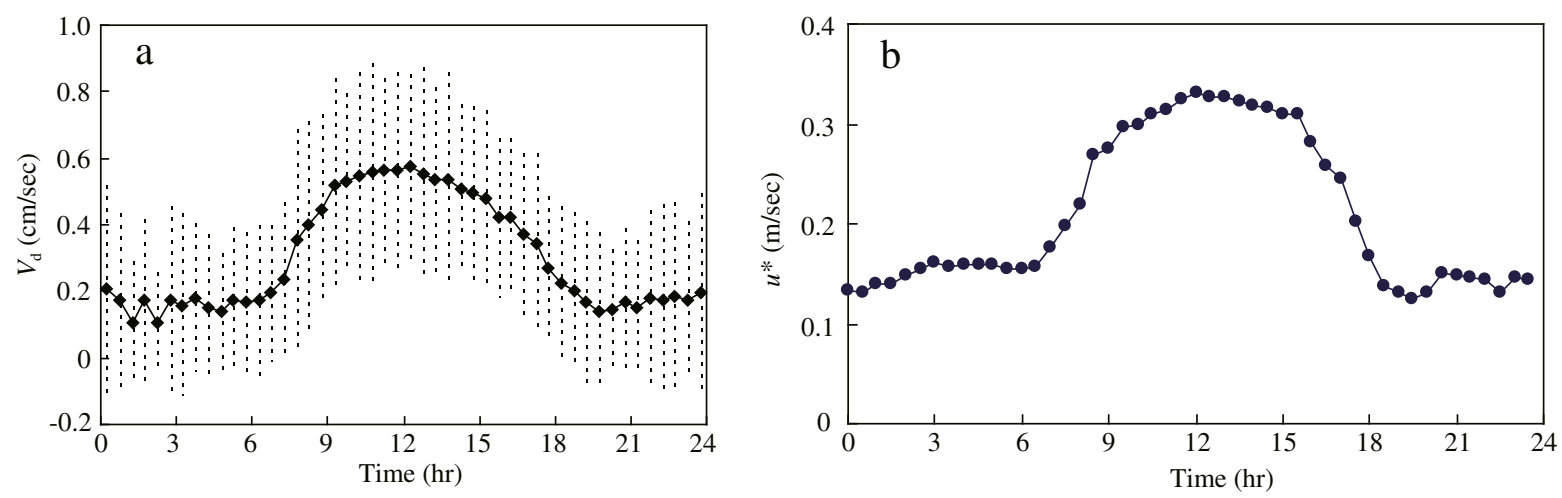

Fig. 4 - Mean diurnal variations of (a) deposition velocity $\left(V_{d}\right)$ and (b) friction velocity $\left(u^{*}\right)$. 

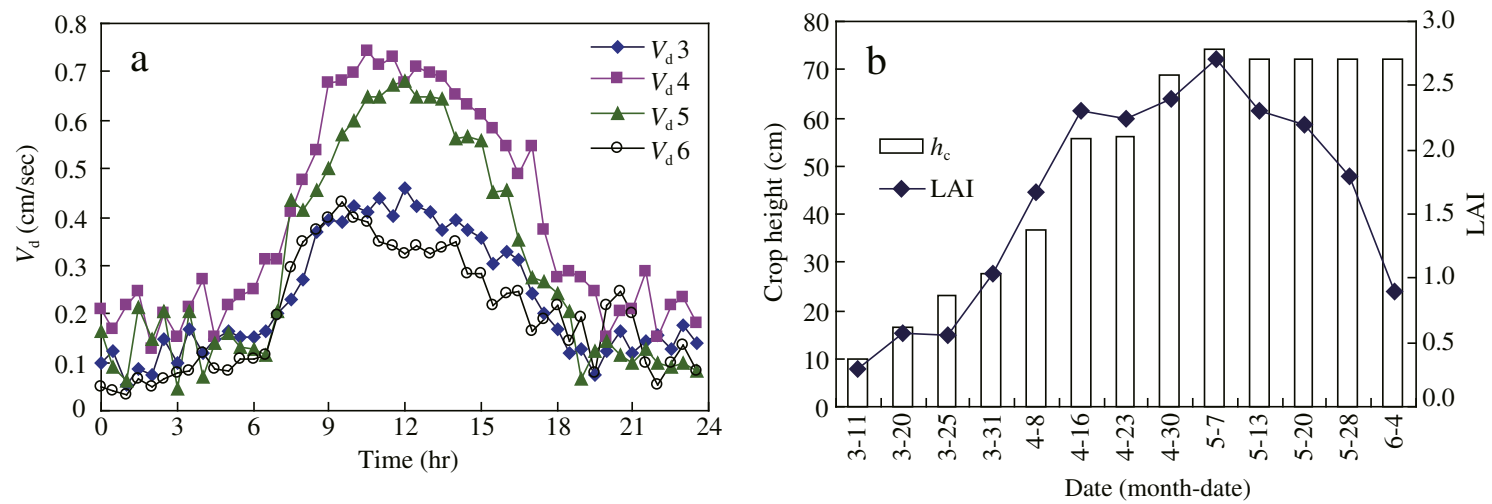

Fig. 5 - (a) Ensemble-averaged diurnal variations of deposition velocity $\left(V_{d}\right)$ during different periods and (b) variations in wheat height $\left(h_{c}\right)$ and leaf area index (LAI) during growing seasons. $v_{d} 3, v_{d} 4, v_{d} 5$, and $v_{d} 6$ are the ensemble-averaged $v_{d}$ of March, April, May, and from 1 to 7 of June 2012, respectively.

\subsubsection{Relationship between $\mathrm{V}_{d}$ and environmental variables} The previous studies showed that the main controlling factors of $V_{d}$ were radiation, air temperature, friction velocity, vapor pressure deficit, soil moisture, and phenology (Wesely and Hicks, 2000; Kurpius et al., 2002; Turnipseed et al., 2009; Zona et al., 2014). In our study, we found that there were obvious positive correlations between $V_{d}$ and both global radiation (Q) and friction velocity $\left(u^{*}\right)$ during the growing stage (Fig. 6). $u^{*}$ could be considered an indirect influencing factor of $\mathrm{O}_{3}$ deposition. On the one hand, the increase of radiation can cause leaf temperature rise, which will result in the opening of stomata to reduce temperature. The opening of stomata will simultaneously let other gases (e.g., $\mathrm{CO}_{2}$ and $\mathrm{O}_{3}$ ) enter plants. On the other hand, radiation increases can also strengthen atmospheric turbulent exchange, i.e., $u^{*}$ becomes large, which allows for greater proximity to stomata via vertical and horizontal transport. In fact, $V_{d}$ is synthetically affected by numerous factors and complex processes, which can be verified by the relatively scattered relationships.

2.2.3. Mean diurnal variations of ozone flux and its uncertainty According to Eq. (2), the magnitude and variation of $F_{0}$ are determined by $\mathrm{O}_{3}$ concentration and $\mathrm{V}_{\mathrm{d}}$. Fig. 7 shows the diurnal variations of mean $F_{o}$ in (a) the growing season and (b) for different periods. Since there is no known biological source of $\mathrm{O}_{3}, \mathrm{~F}_{\mathrm{o}}$ was always directed downward. Because of the rapid increase of $\mathrm{O}_{3}$ concentration and $\mathrm{V}_{\mathrm{d}}$ in the morning, $F_{\circ}$ showed a faster increase until 11:00. From 11:00-16:00, there was relatively slow variation in $F_{0}$, and maximum flux appeared at approximately 14:00, which was between the peak times of $\mathrm{O}_{3}$ concentration and $\mathrm{V}_{\mathrm{d}}$. Beginning at 16:00, $\mathrm{F}_{\mathrm{o}}$ showed a rapid decrease because of the drastic decline of $\mathrm{O}_{3}$ concentration. At night, $F_{o}$ displayed small and smooth changes due to weak changes in concentration and $V_{d}$. The mean $F_{o}$ during daytime and nighttime were -6.9 and $1.5 \mathrm{nmol} /\left(\mathrm{m}^{2} \cdot \mathrm{sec}\right)$, respectively. The maximum measured $F_{\mathrm{o}}$ was $-33.5 \mathrm{nmol} /\left(\mathrm{m}^{2} \cdot \mathrm{sec}\right)$. Due to the differences in $\mathrm{O}_{3}$ concentrations and $V_{d}$ during different months, there were obvious differences in the magnitude and diurnal variation pattern of $F_{0}$ in different months (Fig. 7b). The ensemble-averaged $F_{0}$ in March, April, May, and from 1 to 7 of June were $2.3 \pm 2.0,5.1 \pm 3.7$, $5.5 \pm 5.3$, and $4.5 \pm 3.1 \mathrm{nmol} /\left(\mathrm{m}^{2} \cdot \mathrm{sec}\right)$, respectively.

Although eddy covariance is the best technique for ecosystem flux measurements, it still has some uncertainties. Different corrections or choice of parameters will result in an altered flux (Massman and Lee, 2002). Particularly, due to the sensitivity drift
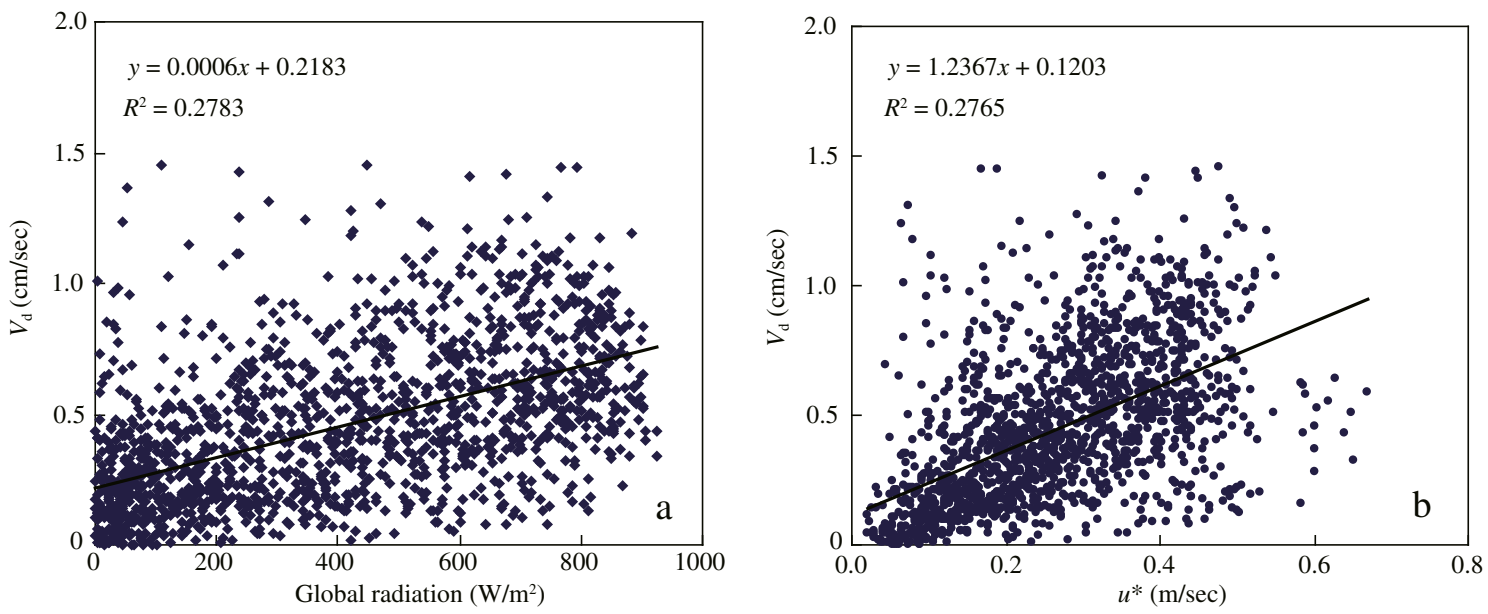

Fig. 6 - (a) Relationships of ozone deposition velocity $\left(V_{d}\right)$ with global radiation and (b) friction velocity $\left(u^{*}\right)$. 

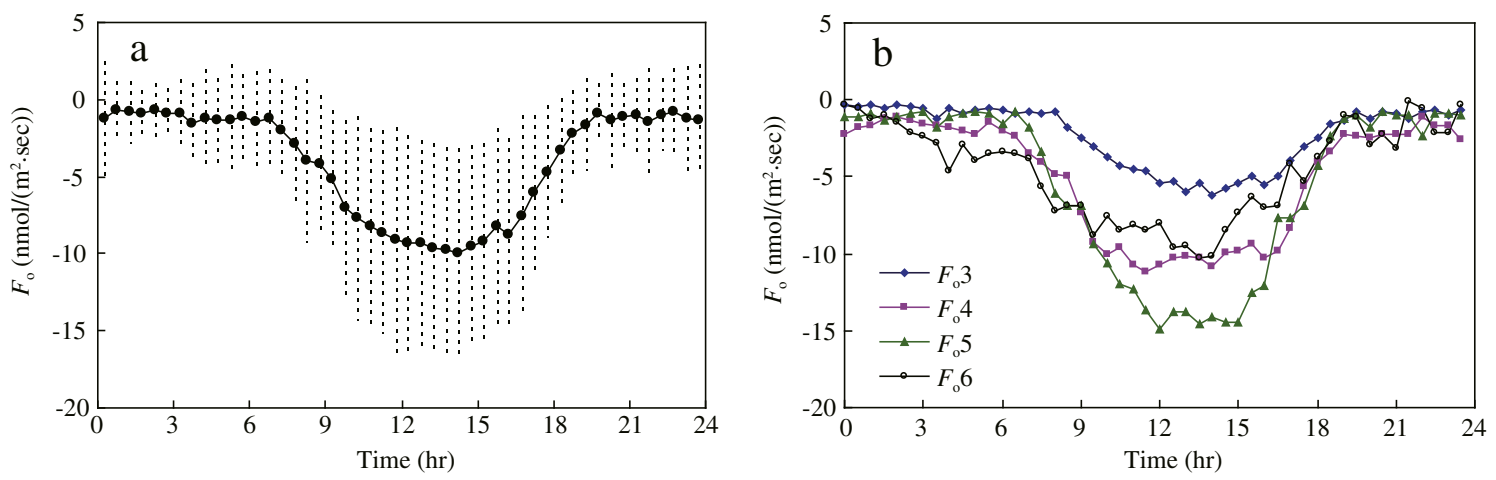

Fig. 7 - Diurnal variations of mean ozone flux $\left(F_{0}\right)$ over wheat field (a) during the entire growing season and (b) during different periods. $F_{o} 3, F_{o} 4, F_{o} 5$, and $F_{o} 6$ are the ensemble-averaged $F_{o}$ of March, April, May, and from 1 to 7 June 2012, respectively.

of the fast-response $\mathrm{O}_{3}$ analyzer, choice of calibration models becomes an added uncertainty source for eddy covariance $\mathrm{O}_{3}$ flux measurements (Muller et al., 2010). Further, to assess the effects of $\mathrm{O}_{3}$ on plants and ecosystems, $F_{\text {st }}$ are more important. $F_{\text {st }}$ and $F_{\text {ns }}$ are usually partitioned by resistance models (Gerosa et al., 2004; Lamaud et al., 2009). The ratio of $F_{\text {st }}$ to $F_{\text {o }}$ usually varies from $1 / 2$ to $1 / 3$ in terrestrial ecosystems, and it is affected by physiological activity and meteorological conditions (Gerosa et al., 2004, 2005; Fowler et al., 2009; Lamaud et al., 2009). The estimation of $F_{\text {st }}$ and additional relevant research will be carried out in the future.

\subsection{Estimation of wheat yield loss based on $\mathrm{O}_{3}$ concentration and its uncertainties}

To estimate $\mathrm{O}_{3}$-induced wheat yield loss, exposure indices must be calculated, and then exposure-response functions can be used to estimate the loss due to ozone. Fig. 8 shows the changes of daily-AOT40 (AOT40 day) and the daily-accumulative AOT40. Clearly, the AOT40 was mostly driven by the AOT40 day during the later part of the growing season (April and May). According to Eqs. (3) and (4), the M7 was equal to $45.1 \mathrm{ppbV}$ and AOT40 was 10.2 ppmV·hr during the growing seasons (3 months).

The exposure-response functions were commonly generated by OTC or FACE experiments. For example, the National Crop
Loss Assessment Network (NCLAN, USA) obtained the M7-based functions using 10-year OTC experiments (Heck et al., 1982; Wang and Mauzerall, 2004). Mills et al. (2007) summarized numerous AOT40-based response functions for some crops obtained by several OTC experiments in Europe and the USA. In China, AOT40-based models have recently been created for the Yangtze River Delta (Feng et al., 2003; Wang et al., 2012). Table 1 shows the yield loss estimations calculated by different ozone exposure-response functions. Note that some functions were corrected with unified units and outputs (Relative Yield Loss (\%), RYL). The current $\mathrm{O}_{3}$-induced wheat yield reduction in the Northwest-Shandong Plain of China was estimated as $12.9 \%$ on average, with considerable variability (5.5\%-23.3\%). In spite of the large differences in the yield loss estimation by different functions, our results still have a certain reference value.

A large discrepancy in the yield loss estimations by two indices and models was reported by Van Dingenen et al. (2009) and Avnery et al. (2011). Wheat yield losses obtained by the M7-based models were significantly lower than those of the AOT40-based models. The inconsistency may be due to the differences in statistical methods used for deriving the exposure-response functions (Van Dingenen et al., 2009). For example, yield loss by AOT40 is relative to that in the charcoal-filtered (i.e., zero- $\mathrm{O}_{3}$ ) air treatment (Mills et al., 2007), while the yield losses calculated by the M7 models

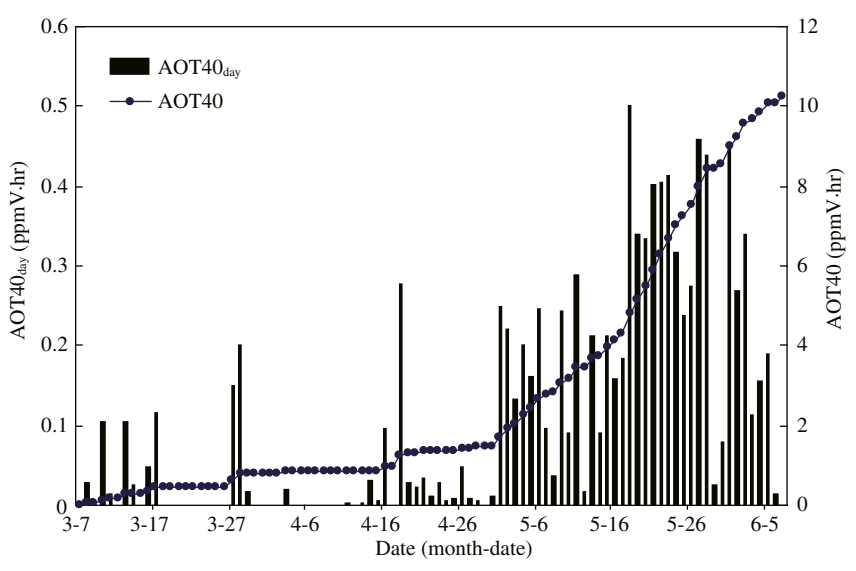

Fig. 8 - Changes in daily and continuously-accumulated $\mathrm{O}_{3}$ concentrations above $40 \mathrm{ppbV}$ (AOT40 day and AOT40) during wheat growing season. 
Table 1-Relative yield loss (RYL) estimation with different $\mathrm{O}_{3}$ exposure-response functions.

\begin{tabular}{lcl}
\hline $\begin{array}{c}\mathrm{O}_{3} \text { exposure-response } \\
\text { function }\end{array}$ & $\begin{array}{c}\text { Relative yield } \\
\text { loss (\%) }\end{array}$ & References \\
\hline $\mathrm{RYL}^{\mathrm{a}}=0.313 \times \mathrm{M} 7-7.8$ & 6.3 & Heck et al. (1982) \\
$\mathrm{RYL}=\exp \left(-(\mathrm{M} 7 / 137)^{2.34}\right) / \mathrm{exp}$ & 5.5 & Wang and \\
$\left(-(25 / 137)^{2.34}\right)$ & 13.2 & Mauzerall (2004) \\
$\mathrm{RYL}=1.296 \times$ AOT40 & 16.4 & Feng et al. (2003) \\
$\mathrm{RYL}{ }^{\mathrm{b}}=1.61 \times$ AOT40 & 23.3 & Wills et al. $(2007)$ \\
$\mathrm{RYL}=2.2795 \times$ AOT40 & & Wang et al. $(2012)$
\end{tabular}

M7: 7-hr (9:00-16:00) mean $\mathrm{O}_{3}$ concentration; AOT40: accumulated hourly ozone concentration above a $40 \mathrm{ppbV}$ threshold.

a The function was corrected with the same unit (ppbV).

b AOT40 unit and output were corrected.

were relative to that at $\mathrm{M} 7=0.025 \mathrm{ppmV}$ (Heck et al., 1982). Adding the yield loss (7.8\%) at M7 $=0.025 \mathrm{ppmV}$ compared to that at $\mathrm{M} 7=0 \mathrm{ppmV}$, the yield loss estimation using M7 should be equal to $14.1 \%$. This value is comparable to the estimations that utilize AOT40 models.

Another source of uncertainty is that the yield response functions may also vary with different wheat cultivars, plant locations, and other environmental conditions when using the same index (Heck et al., 1982; Wang and Mauzerall, 2004; Zhu et al., 2011; Wang et al., 2012). In addition, functions were obtained from OTC experiments and the indices were obtained from natural ecosystems, which may also result in some uncertainties (Wang et al., 2012). Fortunately, more FACE experiments were utilized to study the effects of $\mathrm{O}_{3}$ on crop yield loss, which may improve the assessment accuracy (Zhu et al., 2011; Feng et al., 2012).

\section{Conclusions}

In this study, $\mathrm{O}_{3}$ concentration and flux over a winter wheat field in the Northwest-Shandong Plain were measured via the eddy covariance technique. Slow-response and fast-response analyzers were used to measure absolute $\mathrm{O}_{3}$ concentration and its fluctuation, respectively. Our conclusions can be summarized as follows:

(1) During the observation period (7 March-7 June, 2012), there was an obvious diurnal variation pattern in $\mathrm{O}_{3}$ mean concentration, with the minimum (16.1 ppbV) and maximum (53.3 ppbV) mean concentrations occurring around 6:30 and 16:00, respectively. Daytime and nighttime averages of concentrations were $39.8 \pm 23.1$ and $20.7 \pm 14.1 \mathrm{ppbV}$, respectively. The variation of $\mathrm{O}_{3}$ concentration was mainly affected by solar radiation and temperature.

(2) The diurnal variation of $V_{d}$ can be divided into four phases. The maximum $(0.57 \mathrm{~cm} / \mathrm{sec})$ of mean $V_{d}$ occurred at noon (12:00). Average $V_{d}$ during daytime and nighttime were 0.42 and $0.14 \mathrm{~cm} / \mathrm{sec}$, respectively. The magnitude of $V_{d}$ was influenced by the wheat growing stage, and its variation was significantly correlated with both global radiation and friction velocity.
(3) $\mathrm{O}_{3}$ flux is determined by the $\mathrm{O}_{3}$ concentration and $\mathrm{V}_{\mathrm{d}} \cdot \mathrm{F}_{\mathrm{o}}$ was always directed downward and the maximum of mean $F_{\mathrm{o}}$ appeared at 14:00. The mean $F_{\mathrm{o}}$ during daytime and nighttime were -6.9 and $-1.5 \mathrm{nmol} /\left(\mathrm{m}^{2} \cdot \mathrm{sec}\right)$, respectively.

(4) Using $\mathrm{O}_{3}$ exposure-response functions for wheat yield loss obtained from the USA, Europe, and China, the $\mathrm{O}_{3}$-induced wheat yield reduction at current $\mathrm{O}_{3}$ levels in the Northwest-Shandong Plain of China was estimated as $12.9 \%$ on average, with considerable variability $(5.5 \%-$ 23.3\%). The uncertainties were related to the statistical methods and environmental conditions involved in deriving the exposure-response functions in the respective studies.

\section{Acknowledgment}

This work was supported by the National Natural Science Foundation of China (No. 31070400), the National Basic Research Program of China (No. 2010CB833501-01), the Innovation Project of the Institute of Geographic Sciences and Natural Resources Research, CAS (Grant No. 201003001), and the Max Planck Society (Germany).

\section{R E F E R E N C E S}

Aunan, K., Berntsen, T.K., Seip, H.M., 2000. Surface ozone in China and its possible impact on agricultural crop yields. AMBIO 29 (6), 294-301.

Avnery, S., Mauzerall, D.L., Liu, J.F., Horowitz, L.W., 2011. Global crop yield reductions due to surface ozone exposure: 1 . Year 2000 crop production losses and economic damage. Atmos. Environ. 45, 2284-2296.

Baldocchi, D.D., 2003. Assessing the eddy covariance technique for evaluating carbon dioxide exchange rates of ecosystems: past, present and future. Glob. Chang. Biol. 9 (4), 479-492.

Cape, J.N., 2008. Surface ozone concentrations and ecosystem health: past trends and a guide to future projections. Sci. Total Environ. 400 (1-3), 257-269.

Crutzen, P.J., Lawrence, M.G., Pöschl, U., 1999. On the background photochemistry of tropospheric ozone. Tellus B 51 (1), 123-146.

David, L.M., Nair, P.R., 2011. Diurnal and seasonal variability of surface ozone and NOx at a tropical coastal site: association with mesoscale and synoptic meteorological conditions. J. Geophys. Res. 116. http://dx.doi.org/10.1029/2010JD015076 (D10303).

Dueñas, C., Fernández, M.C., Cañete, S., Carretero, J., Liger, E., 2002. Assessment of ozone variations and meteorological effects in an urban area in the Mediterranean Coast. Sci. Total Environ. 299 (1-3), 97-113.

Falge, E., Baldocchi, D., Olson, R., Anthoni, P., Aubinet, M., Bernhofer, C., et al., 2001. Gap filling strategies for defensible annual sums of net ecosystem exchange. Agric. For. Meteorol. 107 (1), 43-69.

Feng, Z.W., Jin, M.H., Zhang, F.Z., Huang, Y.Z., 2003. Effects of ground-level ozone $\left(\mathrm{O}_{3}\right)$ pollution on the yields of rice and winter wheat in the Yangtze River Delta. J. Environ. Sci. 15 (3), 360-362.

Feng, Z.Z., Kobayashi, K., Ainsworth, E.A., 2008. Impact of elevated ozone concentration on growth, physiology, and yield of wheat (Triticum aestivum L.): a meta-analysis. Glob. Chang. Biol. 14 (11), 2696-2708.

Feng, Z.Z., Tang, H.Y., Uddling, J., Pleijel, H., Kobayashi, K., Zhu, J.G., et al., 2012. A stomatal ozone flux-response relationship to 
assess ozone-induced yield loss of winter wheat in subtropical China. Environ. Pollut. 164, 16-23.

Fowler, D., Pilegaard, K., Sutton, M.A., Ambus, P., Raivonen, M., Duyzer, J., et al., 2009. Atmospheric composition change: ecosystems-atmosphere interactions. Atmos. Environ. 43 (33), 5193-5267.

Gerosa, G., Cieslik, S., Ballarin-Denti, A., 2003. Micrometeorological determination of time-integrated stomatal ozone fluxes over wheat: a case study in Northern Italy. Atmos. Environ. 37 (6), 777-788.

Gerosa, G., Marzuoli, R., Cieslik, S., Ballarin-Denti, A., 2004. Stomatal ozone fluxes over a barley field in Italy. "Effective exposure" as a possible link between exposure- and flux-based approaches. Atmos. Environ. 38 (15), 2421-2432.

Gerosa, G., Vitale, M., Finco, A., Manes, F., Denti, A., Cieslik, S., 2005. Ozone uptake by an evergreen Mediterranean Forest (Quercus ilex) in Italy. Part I: micrometeorological flux measurements and flux partitioning. Atmos. Environ. 39 (18), 3255-3266.

Grünhage, L., Haenel, H.D., Jäger, H.J., 2000. The exchange of ozone between vegetation and atmosphere: micrometeorological measurement techniques and models. Environ. Pollut. 109 (3), 373-392.

Güsten, H., Heinrich, G., Mönnich, E., Sprung, D., Weppner, J., Ramadan, A.B., et al., 1996. On-line measurements of ozone surface fluxes. II. Surface-level ozone fluxes onto the Sahara desert. Atmos. Environ. 30 (6), 911-918.

Heck, W.W., Taylor, O., Adams, R., Bingham, G., Miller, J., Preston, E., et al., 1982. Assessment of crop loss from ozone. J. Air Pollut. Control Assoc. 32 (4), 353-361.

Kelly, N.A., Wolff, G.T., Ferman, M.A., 1984. Sources and sinks of ozone in rural areas. Atmos. Environ. 18 (7), 1251-1266.

Kurpius, M.R., McKay, M., Goldstein, A.H., 2002. Annual ozone deposition to a Sierra Nevada ponderosa pine plantation. Atmos. Environ. 36 (28), 4503-4515.

Lamaud, E., Loubet, B., Irvine, M., Stella, P., Personne, E., Cellier, P., 2009. Partitioning of ozone deposition over a developed maize crop between stomatal and non-stomatal uptakes, using eddy-covariance flux measurements and modelling. Agric. For. Meteorol. 149 (9), 1385-1396.

Li, J.F., Lu, K.D., Lü, W., Li, J., Zhong, L.J., Ou, Y.B., et al., 2014. Fast increasing of surface ozone concentrations in Pearl River Delta characterized by a regional air quality monitoring network during 2006-2011. J. Environ. Sci. 26 (1), 23-36.

Lin, W., Xu, X., Zhang, X., Tang, J., 2008. Contributions of pollutants from North China Plain to surface ozone at the Shangdianzi GAW Station. Atmos. Chem. Phys. 8, 5889-5898.

Ma, J.Z., Tang, J., Zhou, X.J., Zhang, X.H., 2002. Estimates of the chemical budget for ozone at Waliguan Observatory. J. Atmos. Chem. 41 (1), 21-48.

Massman, W.J., Lee, X., 2002. Eddy covariance flux corrections and uncertainties in long-term studies of carbon and energy exchanges. Agric. For. Meteorol. 113 (1-4), 121-144.

Mills, G., Buse, A., Gimeno, B., Bermejo, V., Holland, M., Emberson, L., et al., 2007. A synthesis of AOT40-based response functions and critical levels of ozone for agricultural and horticultural crops. Atmos. Environ. 41 (12), 2630-2643.

Monks, P.S., 2000. A review of the observations and origins of the spring ozone maximum. Atmos. Environ. 34 (21), 3545-3561.

Muller, J.B.A., Percival, C.J., Gallagher, M.W., Fowler, D., Coyle, M., Nemitz, E., 2010. Sources of uncertainty in eddy covariance ozone flux measurements made by dry chemiluminescence fast response analysers. Atmos. Meas. Tech. 3, 163-176.

Musselman, R.C., Lefohn, A.S., Massman, W.J., Heath, R.L., 2006. A critical review and analysis of the use of exposure- and flux-based ozone indices for predicting vegetation effects. Atmos. Environ. 40 (10), 1869-1888.

Padro, J., 1996. Summary of ozone dry deposition velocity measurements and model estimates over vineyard, cotton, grass and deciduous forest in summer. Atmos. Environ. 30 (13), 2363-2369.

Paoletti, E., Manning, W.J., 2007. Toward a biologically significant and usable standard for ozone that will also protect plants. Environ. Pollut. 150 (1), 85-95.

Pleijel, H., Danielsson, H., Ojanperä, K., Temmerman, L.D., Högy, P., Badiani, M., et al., 2004. Relationships between ozone exposure and yield loss in European wheat and potato-a comparison of concentration-and flux-based exposure indices. Atmos. Environ. 38 (15), 2259-2269.

Pleijel, H., Danielsson, H., Emberson, L., Ashmore, M., Mills, G., 2007. Ozone risk assessment for agricultural crops in Europe: further development of stomatal flux and flux-response relationships for European wheat and potato. Atmos. Environ. 41 (14), 3022-3040.

Turnipseed, A.A., Burns, S.P., Moore, D.J.P., Hu, J., Guenther, A.B., Monson, R.K., 2009. Controls over ozone deposition to a high elevation subalpine forest. Agric. For. Meteorol. 149 (9), 1447-1459.

Van Dingenen, R., Dentener, F.J., Raes, F., Krol, M.C., Emberson, L., Cofala, J., 2009. The global impact of ozone on agricultural crop yields under current and future air quality legislation. Atmos. Environ. 43 (3), 604-618.

Vingarzan, R., 2004. A review of surface ozone background levels and trends. Atmos. Environ. 38 (21), 3431-3442.

Wang, X.P., Mauzerall, D.L., 2004. Characterizing distributions of surface ozone and its impact on grain production in China, Japan and South Korea: 1990 and 2020. Atmos. Environ. 38 (26), 4383-4402.

Wang, T., Wong, H.L.A., Tang, J., Ding, A., Wu, W.S., Zhang, X.C., 2006. On the origin of surface ozone and reactive nitrogen observed at a remote mountain site in the northeastern Qinghai-Tibetan Plateau, western China. J. Geophys. Res. 111. http://dx.doi.org/10.1029/2005JD006527 (D08303).

Wang, X.K., Manning, W., Feng, Z.W., Zhu, Y.G., 2007. Ground-level ozone in China: distribution and effects on crop yields. Environ. Pollut. 147 (2), 394-400.

Wang, T., Wei, X.L., Ding, A.J., Poon, C.N., Lam, K.S., Li, Y.S., et al., 2009. Increasing surface ozone concentrations in the background atmosphere of Southern China, 1994-2007. Atmos. Chem. Phys. 9, 6217-6227.

Wang, X.K., Zhang, Q.Q., Zheng, F.X., Zheng, Q.W., Yao, F.F., Chen, Z., et al., 2012. Effects of elevated $\mathrm{O}_{3}$ concentration on winter wheat and rice yields in the Yangtze River Delta, China. Environ. Pollut. 171, 118-125.

Webb, E.K., Pearman, G.I., Leuning, R., 1980. Correction of flux measurements for density effects due to heat and water vapour transfer. Q. J. R. Meteorol. Soc. 106 (447), 85-100.

Wesely, M.L., Hicks, B.B., 2000. A review of the current status of knowledge on dry deposition. Atmos. Environ. 34 (12-14), 2261-2282.

Wilczak, J.M., Oncley, S.P., Stage, S.A., 2001. Sonic anemometer tilt correction algorithms. Bound.-Lay. Meteorol. 99 (1), 127-150.

Xu, X., Lin, W., Wang, T., Yan, P., Tang, J., Meng, Z., et al., 2008. Long-term trend of surface ozone at a regional background station in eastern China 1991-2006: enhanced variability. Atmos. Chem. Phys. 8 (10), 2595-2607.

Yu, G.R., Wen, X.F., Sun, X.M., Tanner, B.D., Lee, X., Chen, J.Y., 2006. Overview of ChinaFLUX and evaluation of its eddy covariance measurements. Agric. For. Meteorol. 137 (3-4), 125-137.

Zahn, A., Weppner, J., Widmann, H., Schlote-Holubek, K., Burger, B., Kuhner, T., et al., 2012. A fast and precise chemiluminescence ozone detector for eddy flux and airborne application. Atmos. Meas. Tech. 5 (2), 363-375.

Zhu, X.K., Feng, Z.Z., Sun, T.F., Liu, X.C., Tang, H.Y., Zhu, J.G., et al., 2011. Effects of elevated ozone concentration on yield of four Chinese cultivars of winter wheat under fully open-air field conditions. Glob. Chang. Biol. 17 (8), 2697-2706.

Zona, D., Gioli, B., Fares, S., De Groote, T., Pilegaard, K., Ibrom, A., et al., 2014. Environmental controls on ozone fluxes in a poplar plantation in Western Europe. Environ. Pollut. 184, 201-210. 